\title{
Pembelajaran batik tetes lilin sebagai alternatif teknik membatik sederhana pada mahasiswa PAUD
}

\author{
Prayitno Prayitno
}

Program Studi Pendidikan Anak Usia Dini, Fakultas Ilmu Pendidikan, Universitas Negeri Yogyakarta. Jalan Colombo No. 1, Karangmalang, Yogyakarta 55281, Indonesia

E-mail: prayprayitno576@uny.ac.id

\section{ARTICLE INFO}

Article history:

Received: 14-8-2019;

Revised: 20-8-2019;

Accepted: 24-8-2019

Keywords: pembelajaran; batik tetes lilin; batik sederhana; learning;

\section{ABSTRACT}

Tujuan penelitian ini adalah untuk mendeskripsikan atau menggambarkan bagaimana pembelajaran membuat batik dengan teknik tetes lilin terhadap mahasiswa Pendidikan Anak Usia Dini (PAUD). Metode penelitian ini menggunakan metode deskriptif. Subjek penelitian ini adalah mahasiswa PAUD salah satu Perguruan Tinggi Negeri di Yogyakarta, sebanyak 36 mahasiswa. Batik tetes lilin adalah teknik membatik pada kain dengan menggunakan media tetesan lilin sebagai perintang warna dan media untuk menghasilkan motif (pengganti canting). Dari hasil penelitian yang didapat menunjukkan bahwa sebagian besar mahasiwa PAUD ini dapat membuat batik tetes lilin. Hal itu dapat dilihat dari hasil karya yang dibuat oleh mahasiswa PAUD tersebut. Hasil karya mahasiswa yang mendapat kriteria Baik 53\%, kriteria Cukup $33 \%$, dan Kurang 14\%. Pembelajaran batik tetes lilin ini dapat dijadikan sebagai alternatif pembelajaran membatik sederhana. Setelah melakukan pembelajaran batik dengan teknik tetes lilin ini, diharapkan Mahasiswa PAUD ketika sudah mengajar dapat mengaplikasikannya terhadap anak didiknya nanti di sekolah. Pembelajaran batik sederhana ini sebagai referensi Mahasiswa PAUD, dapat dikembangkan lagi dan dapat disesuaikan dengan kondisi anak didiknya nanti.

The purpose of this research was to descript or to describe learning to make a batik with drops candle technic to Early Childhood Education college students. The method of this research used described method. The subject of this research is Early Childhood Education student colleges one of the Public Universities in Yogyakarta, as many 36 student colleges. Batik Tetes Lilin is technique to make batik on fabric with use candle drops as covering the color and media to produce the motives (replacement of canting). Results of research obtained shows that most of the Early Childhood Education student colleges can be make a Batik Tetes Lilin. The creation student colleges have got good criteria is 53\%, enough criteria is 33\%, and less criteria is $14 \%$. Learning of Batik Tetes Lilin can be used as alternative learning to make simple batik. After did learning of batik with drops candle technic, expected the Early Childhood Education college student's can apply to students at school. Learning of simple batik as an reference Early Childhood Education college students, can be develop again and can adjust with condition of students.

\section{PENDAHULUAN}

Indonesia adalah negara yang memiliki beraneka ragam budaya, salah satunya adalah batik. Batik merupakan karya seni yang sudah ada sejak zaman kerajaan. Secara teknis ataupun estetis seni batik merupakan bentuk tradisi yang ada sejak zaman Hindu. Seiring berjalannya waktu diteruskan oleh tradisi zaman Kerjaan Islam yang disertai oleh unsur-unsur baru (Yudoseputro, 2008: 216). Kebudayaan batik diwariskan dari generasi ke generasi selanjutnya. Hal tersebut tampak pada motif batik yang mencerminkan identitas keluarga tertentu, sebagian motif batik menggambarkan status seseorang. Selain itu juga sebagian motif tradisional menjadi ciri khas dipakai oleh keluarga Keraton 
Prayitno

Yogyakarta dan Surakarta (Prasetyo, 2016, p. 53). Sampai saat ini batik berkembang pesat baik itu desain motif ataupun hal yang lainnya. Patut kita banggakan karena batik telah diakui oleh dunia internasional pada tanggal 2 Oktober 2009 oleh UNESCO (salah satu badan khusus PBB), sebagai Warisan Kemanusiaan untuk Budaya Lisan dan Nonbendawi (Masterpieces of the Oral and Intangible Heritage of Humanity).

Sebagai bangsa Indonesia terutama calon pendidik PAUD diharapkan dapat melestarikan budaya batik, salah satunya dengan cara mengajarkannya kepada anak didiknya nanti di sekolah. Mahasiswa PAUD setidaknya dapat memahami dan dapat mempraktekkan pembelajaran batik. Hal itu dikarenakan di sekolah atau lembaga pendidikan PAUD tidak lepas dari pembelajaran seni rupa, salah satunya adalah pembelajaran batik. Sejatinya pada proses membatik media yang digunakan adalah canting sebagai alat perintang warna, namun untuk anak-anak akan kesulitan menggunakannya. Hal tersebut dikarenakan memerlukan keahlian, keterampilan dan kehati-hatian dari pembuatnya. Disamping tingkat kesulitan yang tinggi untuk anak-anak, juga alat dan bahan yang harus disiapkan tidak sedikit, sehingga biaya untuk melakukan pembelajaran seperti ini termasuk besar. Pembelajaran batik pada anak-anak sangatlah perlu, walaupun tidak dipraktekkan secara detail seperti batik tulis. Pada anak-anak dapat diajarkan pembelajaran batik versi sederhana, baik alat, bahan, ataupun teknik.

Pada kesempatan ini menawarkan media pembelajaran alternatif batik sederhana yaitu batik tetes lilin. Batik tetes lilin adalah teknik membatik pada kain dengan menggunakan media tetesan lilin sebagai perintang warna dan media untuk menghasilkan motif (pengganti canting). Secara teori membuat atau menggambar motif dengan teknik tetes lilin ini dapat dikategorikan sebagai batik. Hal tersebut dapat kita pahami kata batik menurut KBBI adalah kain bergambar yang pembuatannya secara khusus dengan menuliskan atau menerakan malam pada kain itu, kemudian pengolahannya diproses dengan cara tertentu. Malam yang dimaksud disini adalah sejenis lilin. Kegiatan membatik adalah kegiatan membuat gambar (motif) pada kain katun atau sutra melalui proses rintang celup. Proses tersebut dinamakan rintang celup, karena ada bagian yang terintangi atau terhalangi pewarna masuk ke kain oleh motif yang dibentuk dari torehan lilin (Tocharman, 2006, p.190). Jadi pada proses pewarnaan bagian gambar yang terdapat malam (lilin) tidak terkena warna, sehingga gambar yang terkena malam (lilin) berwarna putih kain. Inti dari batik adalah ada pada tekniknya, adanya proses perintang warna, dan media yang digunakan adalah malam atau lilin untuk membuat motifnya. Tidak semua kain yang bermotif dapat dikatakan sebagai batik jika tekniknya berbeda, misalnya kain yang bermotif itu dibuat dengan teknik sablon (cetak saring) atau printing textil. Dari uraian tersebut dapat dikatakan bahwa membuat motif pada kain dengan teknik tetes lilin disebut juga sebagai batik. Selain teknik yang sederhana alat dan bahan yang digunakan pun lebih sederhana dibanding membatik dengan menggunakan canting. Proses yang sederhana ini diharapkan mahasiswa PAUD tertarik, mudah memahami, serta dapat mengajarkannya kepada anak didiknya nanti.

Pembelajaran membatik mrupakan pembelajaran seni yang bermanfaat bagi peserta didik. Martono dan Retnowati $(2009$, p. 3) berpendapat apresiasi dan kreasi dapat dikembangkan oleh peserta didik melalui pembelajaran seni dan keterampilan. Pembelajaran tersebut mengandung nilai estetik, terampil, kreatif, dan tekun yang akan bermanfaat bila diaplikasikan pada kegiatan berkesenian

Sebelumnya sudah ada penelitian sejenis mengenai pembelajaran membatik sederhana yang diteliti oleh Nurul Hidayah, dengan judul "Upaya Meningkatkan Kemampuan Membatik Cap dengan Media Cap Sederhana di SMPN 10 Kota Bandung". Namun pada pembahasan ini difokuskan pada teknik batik cap sederhana. Menurut Hidayah (2016, p. 85) menjelaskan bahan-bahan bekas seperti besi, paku, cetakan kue, karet sandal, kayu dan sebagainya yang ada di sekitar kita dapat dijadikan media cap sederhana untuk membuat batik cap. Media tersebut dijadikan sebagai alat cap dan menghasilkan pola-pola motif yang unik. Dari hasil penelitian itu dapat disimpulkan bahwa membatik cap dengan media cap sederhana membantu mengembangkan siswa memahami serta mempraktekkan dalam membuat batik cap (Hidayah, 2016, p. 88).

PP RI Nomor 14 Tahun 2005 (Tentang Guru dan Dosen) Pasal 10 ayat 1, menjelaskan kompetensi guru adalah meliputi kompetensi pedagogik, kompetensi kepribadian, kompetensi profesional, dan kompetensi sosial. Kompetensi profesional inilah yang harus dikuasai oleh calon guru (mahasiswa PAUD). Kompetensi profesional, kemampuan guru dalam menguasai bahan ajar atau materi. Baik itu pengetahuan teori pembelajaran atau pun praktek dalam pembelajaran, selain itu wajib menguasai pengetahuan kurikulum dan landasan pendidikan. Guru yang profesional dalam membimbing anak didik harus memenuhi standar kompetensi yang ditetapkan dalam Standar Nasional 
Prayitno

Pendidikan.

\section{METODE}

Penelitian ini menggunakan metode deskripstif. Mendeskripsikan serta menjelaskan keadaan yang sebenarnya maupun sebaliknya, seperti bentuk, aktivitas, karakteristik, perubahan, hubungan kesamaan, dan sebagainya merupakan metode penelitian deskriptif (Sukmadinata, 2013, p. 72). Pada penelitian ini mendeskripsikan dan menganalisis penerapan pembelajaran batik dengan teknik tetes lilin kepada mahasiswa PAUD (Pendidikan Anak Usia Dini).

Subjek penelitian ini adalah mahasiswa PAUD salah satu perguruan tinggi negeri di Yogyakarta. Mahasiswa yang mengikuti kegiatan ini berjumlah 36 mahasiswa. Dalam melakukan analisis data pembelajaran batik tetes lilin sebagai alternatif teknik membatik sederhana pada mahasiswa PAUD, penulis bersumber dari data yang terkumpul. Data-data yang dikumpulkan berasal dari kegiatan mempraktekkan langsung di tempat penelitian dan dari hasil dokumentasi. Kemudian penulis menganalisis hasil karya batik tetes lilin yang dibuat oleh mahasiswa PAUD tersebut.

Dalam menganalisis data, penulis menggunakan instrumen penelitian. Instrumen adalah hal yang paling penting dalam sebuah penelitian. Kualitas penelitian ditentukan oleh kualitas instrumen, dari instrumen tersebut diperoleh data yang akan menjadi dasar temuan dan dijadikan sebagai kesimpulan (Arifin, 2014, p. 225). Pada instrumen ini berupa rubrik penilaian menggunakan skala deskriptif dan skor, untuk mengukur aspek yang akan dinilai penulis. Skala deskriptif ini di dalamnya terdapat Baik, kategori Cukup, dan kategori Kurang (Kunandar, 2015).

\section{HASIL DAN PEMBAHASAN}

Sebelum memulai proses pembuatan karya batik tetes lilin ini, terlebih dahulu siapkan alat dan bahan yang dibutuhkan yaitu lilin batang, pensil, kain mori (sekitar $30 \mathrm{~cm}$ x $40 \mathrm{~cm}$ ), baskom kecil (untuk tempat pewarna), panci, tali rapia (untuk meniriskan karya), pewarna Napthol atau pewarna Parrot, dan soda abu (untuk melorod atau menghilangkan lilin). Berikut langkah-langkahnya:

\section{Pertama}

Langkah pertama adalah membuat sketsa pada kain menggunakan pensil atau bisa juga membuat sketsa terlebih dahulu pada kertas hvs. Setelah sketsa sudah jadi, kemudian outline sketsa tersebut ditebalkan dengan spidol warna hitam. Setelah itu sketsa tersebut diciplak pada kain, dengan cara posisi sketsa kertas diletakkan di bawah kain dan kain mori diletakkan di atas kertas sketsa. Selanjutnya tebalkan sketsa tersebut pada kain (jiplak) menggunakan pensil. Outline sketsa yang ditebalkan dengan spidol warna hitam akan terlihat ketika dijiplak pada kain, karena kain ini berwarna putih sehingga agak tembus pandang.

lainnya. Caranya nyalakan lilin, kemudian lilin tersebut fokuskan pada outline sketsa, dan mulailah meneteskan lilin perlahan- lahan. Untuk menghasilkan tetesan yang terpisah, posisi lilin pada saat meneteskan pada sketsa harus cepat bergerak dan berpindah. Hal tersebut untuk menghindari tetesan lilin menempel diluar outline sketsa yang tidak diharapkan. Dalam menentukan bentuk tetesan lilin seperti ini tergantung dari selera pembuatnya, titik yang dibuat rapat atau agak renggang. Untuk mendapatkan hasil yang unik dan berbeda dari yang lainnya dianjurkan bereksperimen mencoba berbagai bentuk. 


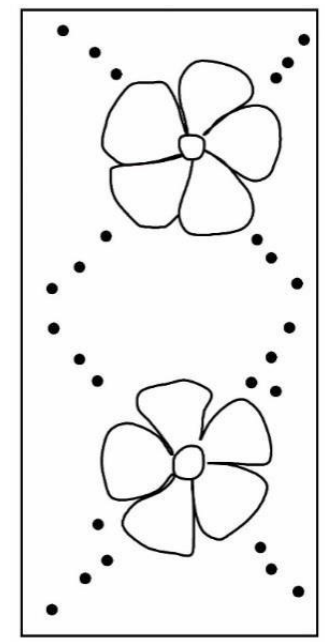

Gambar 1. Contoh Sketsa

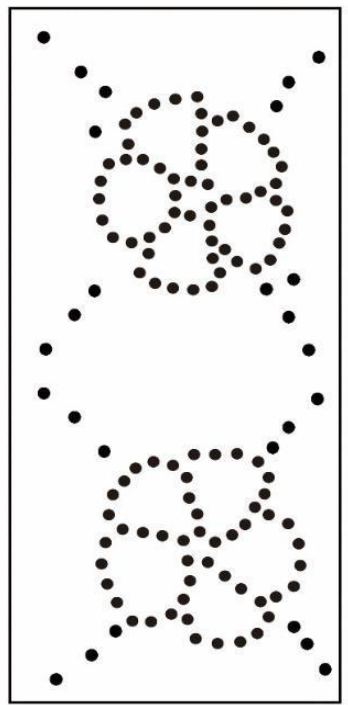

Gambar 2. Contoh Tetesan Terpisah

\section{Kedua}

Selain tetesan lilin terpisah, ada juga tetesan lilin menempel. Tetesan lilin menempel terbentuk karena titik tetesan yang satu dengan titik tetesan yang lainnya hampir tidak memiliki jarak, sehingga kesan yang terlihat menempel. Cara meneteskannya hampir sama dengan tetesan yang terpisah. Langkah kedua adalah menetaskan lilin mengikuti outline sesuai sketsa yang dibuat. Supaya hasil tetesan lilin tidak menempel pada lantai, baiknya diberi alas kertas pada bagian bawah kain. Bentuk tetesan yang dibuat boleh tetesan terpisah atau juga tetesan menempel.

Tetesan lilin terpisah terbentuk karena memiliki jarak antara titik tetesan yang satu dengan titik tetesan yang lilin, kemudian lilin tersebut fokuskan pada outline sketsa, dan mulailah meneteskan lilin perlahan-lahan. Untuk menghasilkan tetesan yang menempel, posisi lilin saat meneteskan pada sketsa dibiarkan sebentar sampai titik tetesannya menempel dengan titik tetesan yang lainnya. Untuk mendapatkan hasil yang unik dan berbeda dari yang lainnya dianjurkan bereksperimen mencoba berbagai bentuk.

Bentuk penggabungan tetesan lilin yang terpisah dengan tetesan lilin yang menempel juga bisa jadi pilihan lain. Misalnya objek utama menggunakan bentuk tetesan yang menempel, kemudian aksen atau variasi lainnya menggunakan tetesan yang terpisah. 
Prayitno

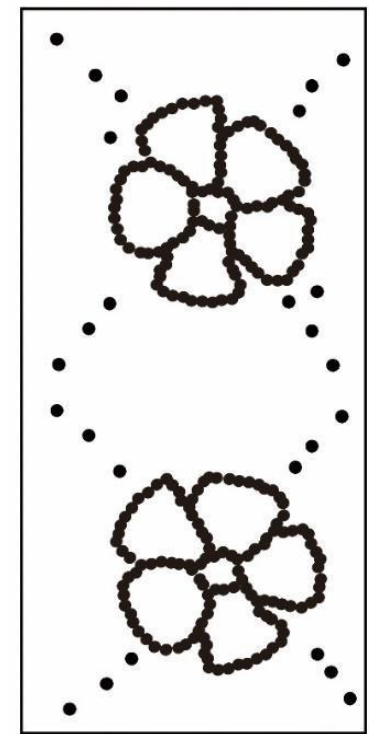

Gambar 3. Contoh Tetesan Menempel

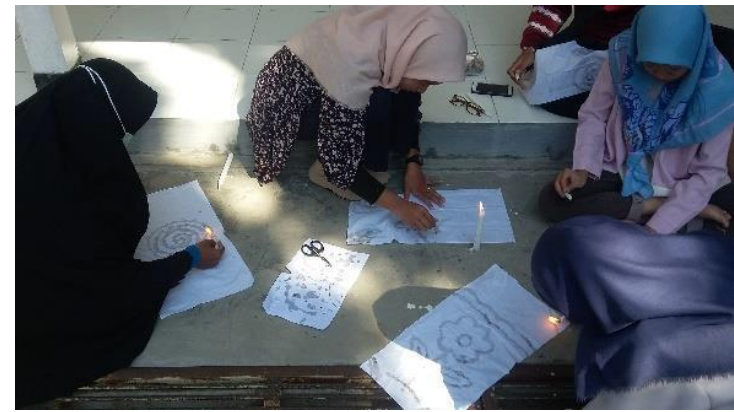

Gambar 4. Kegiatan Meneteskan Lilin

\section{Ketiga}

Langkah ketiga mewarnai kain bervariasi. Supaya tangan tidak kotor atau terkena pewarna dianjurkan menggunakan sarung tangan plastik.

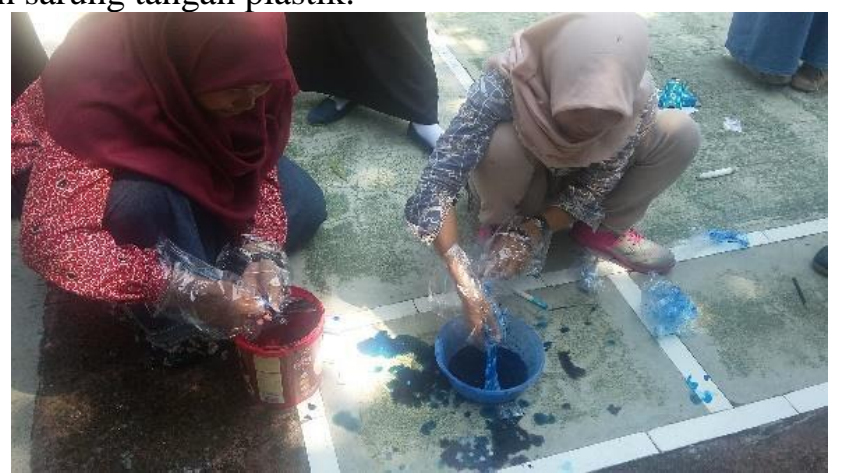

Gambar 5. Proses Pewarnaan

\section{Keempat}

Langkah keempat adalah meniriskan kain yang sudah diwarnain, menggunakan tali rapia yang dibentangkan. Pada saat proses meniriskan tidak terkena matahari langsung. Tunggu sampai air sudah tidak menetes lagi, dan setelah itu bilaslah dengan air bersih. 


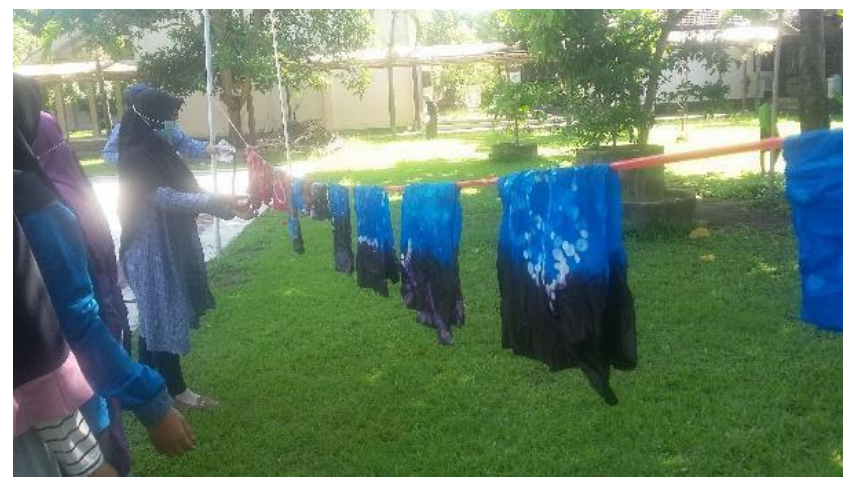

Gambar 6. Meniriskan Karya

\section{Kelima}

Langkah kelima adalah melorod atau proses menghilangkan lilin. Caranya yaitu rebus air pada panci, tunggu sampai mendidih. Setelah mendidih campurkan yang sudah diteteskan lilin. Pada proses pewarnaan bisa menggunakan pewarna Naphtol atau pewarna Parrot. Pada praktek kali ini menggunakan pewarna Napthol, tempatpewarnanya menggunakan dua baskom. Untuk melarutkan pewarna awal menggunakan air panas, kemudian dicampur dengan air biasa. Dalam penggunaan warna lebih baik lebih dari satu warna, supaya lebih abu soda secukupnya. Kemudian masukan kain atau karya batik tersebut. aduk supaya panasnya merata dengan sumpit kayu atau yang berbahan kayu. Proses pelorodan ini membutuhkan waktu 3-5 menit. Apabila lilin yang menempel pada kain sudah hilang, setelah itu dibilas dengan air bersih dan tiriskan.

Pada contoh ini menggambarkan motif flora, yaitu stilasi motif bunga dan dipinggirnya seolah ada ranting yg menjalar. Ranting yang menjalar mirip seperti motif sulur, namun pada motif ini distilasikan oleh visual titik-tik. Salah satu motif flora yang populer adalah motif sulur. Motif hias ini sering kita jumpai pada motif ukiran mebel, kain batik dan sebagainya. Bentuk dari sulur ini adalah seperti tumbuhan menjalar yang berbentuk melengkung yang masih muda. Ragam hias ini sudah ada pada zaman kerajaan Hindu di Indonesia, hal ini diungkapkan oleh Yudoseputro (1986, p. 83) bahwa motif sulur merupakan motif yang begitu terkenal pada kerajaan Hindu. Peninggalan motif sulur tampak pada detail ukiran yang ada pada bangunan istana. Gambar 7 dan Gambar 8 merupakan hasil karya batik sederhana dengan teknik tetes lilin bermotif flora.

Berhubung tidak dapat disajikan satu persatu, maka penulis memberikan sampel atau contoh karya batik tetes lilin lain yang dibuat mahasiswa PAUD dengan desain berbeda. Berikut ini contoh batik lilin desain motif geometris. Kalau dihubungkan dengan motif tradisional, motif geometris adalah motif yang tertua. Parmono (2013, p. 142) motif geometris adalah motif yang memiliki usia tertua dibanding motif yang lain. Motif geometris terdapat pada sebagian besar karya ukiran maupun bentuk motif pada kain. Pada umumnya motif ini mengandung arti mengenai pusat pemerintahan maupun kerajaan.

Setelah proses pembuatan karya batik selesai, selanjutnya adalah proses penilaian atau menganalisis karya berdasarkan instrumen penilaian yang sudah dibuat. Aspek yang dinilai adalah motif dan warna. Pada aspek motif, indikator deskripsinya yaitu apabila bentuk motif yang dibuat terlihat jelas dan tidak samar-samar, skor yang diberikan 1. Karya yang dibuat dan tetesan lilin sesuai dengan sketsa, maka skor yang diberikan 1. Selanjutnya kerapihan, apabila karya yang dibuat tidak terlihat kotor dan tidak terlihat bercak-bercak, maka skor yang diberikan adalah 1. Sebaliknya apabila ada aspek yang tidak terlihat maka diberi nilai 0 .

Pada aspek warna, indikator deskripsinya adalah karya yang dibuat menggunakan lebih dari satu pewarna, misalnya tidak hanya kuning saja tapi ada warna hijau, biru, dan sebagainya (skor maksimal yang diberikan 1. Pada proses pewarnaan karya yang dihasilkan pada kain terlihat penuh dan rata warnanya (skor maksimal yang diberikan 1. Terakhir, apabila karya yang dibuat menghasilkan perpaduan warna yang serasi atau harmonis mendapat skor maksimal 1. Sehingga nilai total yang didapat apabila karya yang dibuat mendapat skor maksimal adalah 18. Tabel 1 merupakan rubrik penilaian yang dijadikan sebagai instrumen untuk mengukur hasil karya batik tetes lilin. 
Jurnal Pendidikan Anak, 8 (1), 2019

Prayitno

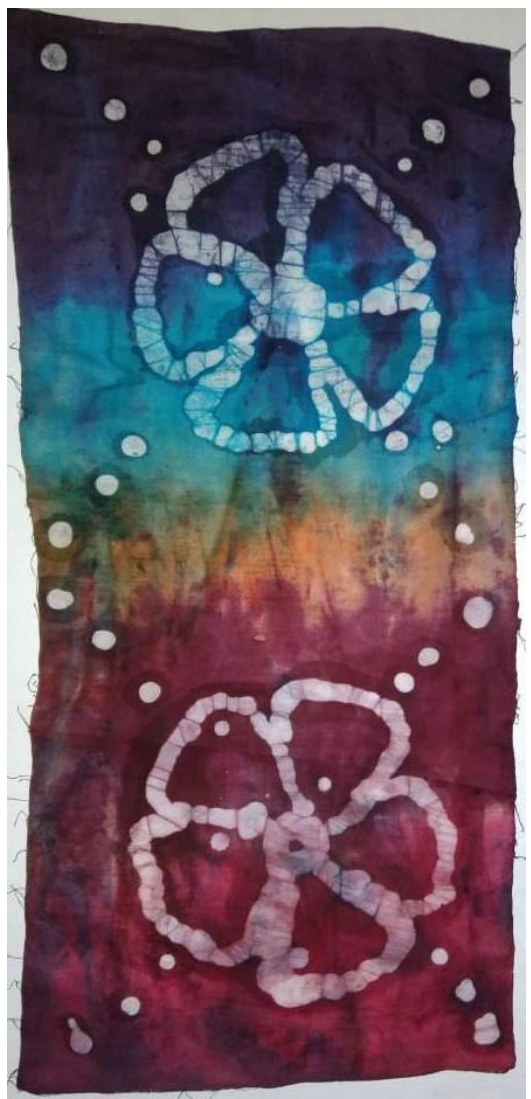

Gambar 7. Hasil Karya Batik Tetes Lilin Bermotif Bunga atau Flora

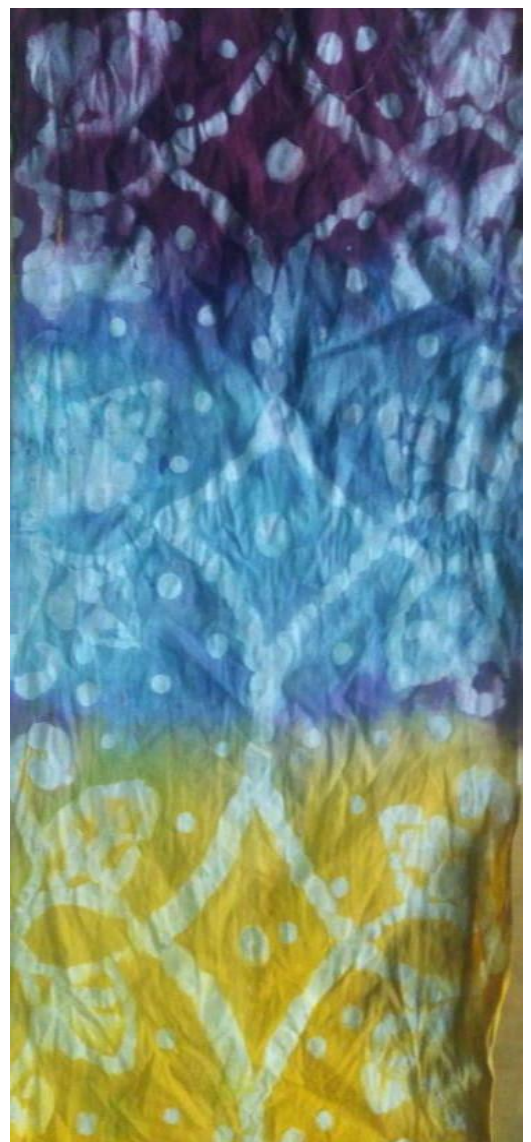

Gambar 8. Hasil Karya Batik Tetes Lilin Bermotif Geometris 
Tabel 1. Aspek Penilaian

\begin{tabular}{|c|c|c|c|c|}
\hline \multirow{2}{*}{ Aspek } & \multirow{2}{*}{ Deskripsi } & \multicolumn{3}{|c|}{ Skor } \\
\hline & & 3 & 2 & 1 \\
\hline \multirow[t]{3}{*}{ Motif } & Terlihat jelas bentuknya & Jika terlihat 3 & Jika terlihat & Jika terlihat \\
\hline & $\begin{array}{l}\text { Sesuai dengan sketsa yang dibuat } \\
\text { Rapih (tidak banvak bercak) }\end{array}$ & poin & hanya 2 Poin & hanya 1 Poin \\
\hline & & 3 & 2 & 1 \\
\hline \multirow[t]{3}{*}{ Warna } & Menggunakan lebih dari satu pewarna & Jika terlihat 3 & Jika terlihat & Jika terlihat \\
\hline & Terlihat penuh dan merata pada kain & poin & hanya 2 Poin & hanya 1 poin \\
\hline & Menggunakan kolaborasi warna gelap dan terang & & & \\
\hline \multicolumn{2}{|c|}{ Skor Maksimal } & 6 & & \\
\hline
\end{tabular}

Selain menggunakan instrumen tersebut, penulis juga menggunakan pedoman penilaian yang dikutip dari Kunandar (2015). Pedoman penilaian ini untuk menentukan kriteria hasil karya batik tetes lilin yang dibuat oleh mahasiswa PAUD. Krieria yang diberikan adalah Baik, Cukup, dan Kurang. Mahasiwa yang karyanya mendapat skor maksimal 6, maka kriteria yang didapat adalah Baik. sebaliknya apabila mendapat skor 2,66 ke bawah, maka kriteria yang didapat adalah kurang. Tabel 2 merupakan tabel pedoman penilaian:

Tabel 2 Pedoman Penilaian (Kunandar, 2015)

\begin{tabular}{ll}
\hline Rentang Skor & Kriteria \\
\hline $5,34-6$ & Baik \\
$2,66-5,34$ & Cukup \\
$2-2,66$ & Kurang \\
\hline
\end{tabular}

Dari hasil pembelajaran batik tetes lilin yang diterapkan terhadap mahasiswa PAUD serta hasil analisis karya, didapatkan bahwa yang mendapat kriteria Baik berjumlah 19 Mahasiswa, mendapat kriteria Baik berjumlah 12 mahasiswa, mendapat kriteria Cukup berjumlah 5 mahasiswa. Apabila dikonversi ke dalam presentase yang mendapat kriteria Sangat Baik 53\%, mendapat kriteria Cukup $33 \%$, yang mendapat kriteria Kurang $14 \%$.

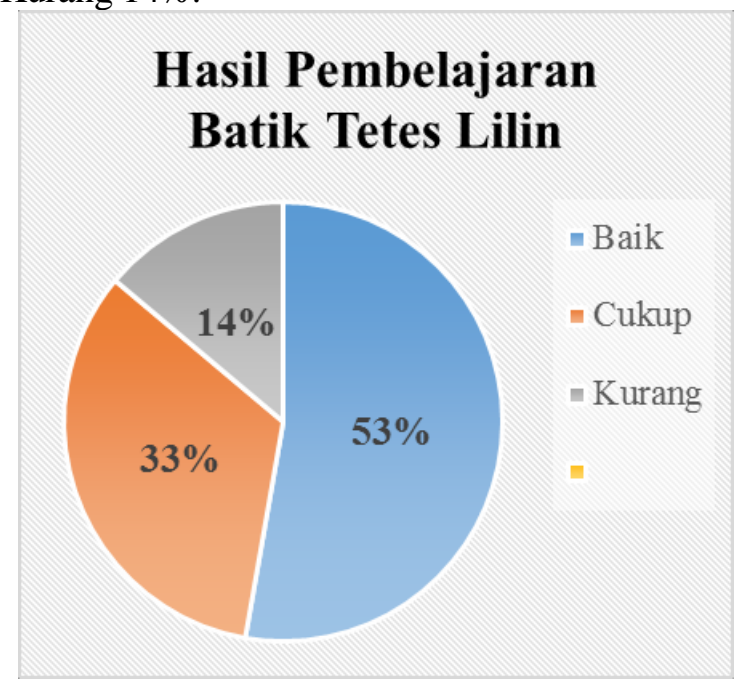

Gambar 9. Hasil Pembelajaran Batik Tetes Lilin

Pembelajaran batik tetes lilin yang diterapkan terhadap mahasiswa PAUD, sebagian besar mahasiswa dapat berkreasi dengan baik. Hal tersebut terlihat selama proses pembelajaran dari memperoleh ide desain motif, membuat sketsa, meneteskan lilin pada kain, pewarnaan, pelorodan, dan sampai karyanya selesai dibuat. Walaupun masih ada mahasiswa yang membuat karya kurang baik, namun presentasinya kecil.

Dari hasil analisis karya yang didapat, bahwa kelima karya batik tetes lilin yang mendapatkan kriteria kurang yaitu dikarenakan tidak terlihat jelas bentuk motifnya, tidak sesuai sketsa, tidak menggunakan warna lebih dari satu, dan tidak menggunakan kolaborasi warna gelap dan terang (sehingga total skor 2). Motif yang bentuknya terlihat samar-samar dikarenakan masih kurang 
Prayitno

mengontrol ketika lilin menetes pada sketsa, sehingga menetes diluar sketsa, dan akhirnya hasilnya tidak sesuai dengan sketsa awal yang dibuat. Karya yang menggunakan satu warna dikarenakan saat mencampur warna tidak sesuai prosedur, akhirnya warna yang timbul tidak terlihat warna gelap dan terang.

Sebagian mahasiswa PAUD yang ada di sini, ketika SMA mereka sudah diperkenalkan dan diajarkan pembelajaran membatik. Jadi sebagian mahasiswa sudah memiliki keterampilan serta pengetahuan tentang membatik. Data itulah yang membantu membuat hasil karya dengan kriteria sangat baik lebih banyak. Teknik dengan tetesan lilin bagi mahasiswa PAUD merupakan teknik membatik yang baru dipraktekkan, karena sebelumnya di SMA mereka belajar membatik dengan menggunakan canting.

Pembelajaran membatik yang diterapkan pada mahasiswa selain dapat berkreasi membuat batik, secara tidak langsung juga membantu membentuk karakter yang positif. Berdasarkan hasil hasil penelitian yang dilakukan oleh Mahliana \& Mustikarini (2013, p. 132) melalui seni batik dapat membentuk karakter positif di antaranya toleransi, religius, disiplin, kerja keras, demokratis, rasa ingin tahu, semangat kebangsaan, cinta tanah air, komunikatif, peduli lingkungan, peduli sosial, tanggung jawab, dan menghargai prestasi.

Karakter positif yang nampak pada praktek pembelajaran batik tetes lilin adalah disiplin, kreatif, tanggung jawab, dan menghargai prestasi atau karya. Disiplin menetaskan lilin mengikuti pola sketsa yang dibuat oleh mahasiswa tersebut. Kreatif dalam memunculkan ide- ide serta mengkombinasi antara bentuk dan warna yang dipakai. Bertanggung jawab atas karya yang dibuat sampai selesai berdasarkan langkah-langkah pembuatan. Membatik membutuhkan proses yang lama, memerlukan kesabaran dalam membuatanya, sehingga mahasiswa belajar menghargai karya yang dibuat baik dirinya sendiri ataupun karya yang dibuat oleh temannya. Karakter positif ini diharapkan diaplikasikan mahasiswa PAUD pada kehidupan sehari-sehari di lingkungan pendidikan (kampus), di lingkungan masyarakat dan di lingkungan keluarga.

Pada hasil pembuatan batik sederhana yang dibuat dengan tetesan lilin ini ada yang unik. Keunikan tersebut adalah adanya efek retakan atau terlihat seperti serat-serat pada motif yang timbul dibuat oleh tetesan lilin. Selain itu bentuk motif yang dihasilkan berupa titik-titik yang terpisah atau titik-titik yang ditumpuk atau menempel. Keunikan inilah hanya dapat dicapai dengan teknik tetes lilin.

\section{SIMPULAN}

Dari hasil pembelajaran batik tetes yang diterapkan terhadap mahasiswa PAUD dapat disimpulkan bahwa sebagian besar mahasiwa PAUD ini dapat membuat batik dengan teknik tetes lilin. Hal itu dapat dilihat dari hasil karya yang dibuat oleh mahasiswa PAUD. Hasil karya mahasiswa yang mendapat kriteria Baik 53\%, kriteria Cukup 33\%, dan Kurang 14\%. Setelah melakukan pembelajaran batik dengan teknik tetes lilin ini, diharapkan Mahasiswa PAUD ketika sudah mengajar dapat mengaplikasikannya terhadap anak didiknya nanti di sekolah. Pembelajaran batik sederhana ini sebagai referensi Mahasiswa PAUD, dapat dikembangkan lagi dan dapat disesuaikan dengan kondisi anak didiknya nanti.

Pembelajaran batik tetes lilin menanamkan karakter positif di antaranya disiplin, kreatif, tanggung jawab, dan menghargai prestasi atau karya. Selain itu karya yang dibuat memiliki keunikan terseniri. Keunikan tersebut adalah adanya efek retakan atau terlihat seperti serat-serat pada motif yang timbul dibuat oleh tetesan lilin. Selain itu bentuk motif yang dihasilkan berupa titik-titik yang terpisah atau titik-titik yang ditumpuk atau menempel.

Semoga karya tulis ilmiah ini bermanfaat sebagai referensi di dunia pendidikan baik untuk mahasiswa PAUD ataupun guru PAUD yang sudah mengajar di sekolah.

\section{UCAPAN TERIMA KASIH}

Terima kasih yang pertama ditunjukkan kepada Allah SWT, yang telah memberikan nikmat sehat kepada penulis, sehingga dapat menyelesaikan karya tulis ini. Karya tulis ilmiah ini juga tidak luput dari bantuan orang lain. Sebagai penulis ingin mengucapkan terima kasih kepada mahasiswa PAUD angkatan 2017 salah satu Perguruan Tinggi Negeri di Yogyakarta. Berkat kerjasama dan bantuan dari Mahasiswa PAUD, karya tulis ilmiah atau penelitian ini berjalan dengan lancar dan selesai. 
Prayitno

\section{DAFTAR PUSTAKA}

Arifin, Z. (2014). Penelitian pendidikan, metode dan paradigma Baru. Bandung: Rosdakarya.

Depdiknas. (2015). Undang-undang guru dan dosen. Yogyakarta: Pustaka Mahardika.

Hidayah, N. (2016). Upaya meningkatkan kemampuan membatik cap dengan media cap sederhana di SMPN 10

Kota Bandung. Prosiding seminar nasional pendidikan seni dan aplikasi pembelajaran berbasis kreativitas dalam pengembangan karakter anak usia dini. Bandung: 7 Desember 2015. 80-89.

Kunandar. (2015). Penilaian autentik. Jakarta: Raja Grafindo Persada.

Mahliana, L., \& Mustikarini, I.D. (2013). Pendidikan karakter anak melalui seni batik. Citizenship $\begin{array}{lllll}\text { Jurnal Pancasila dan Kewarganegaraan, } & 1 & \text { (2), 119-134. }\end{array}$ http://doi.org/10.25273/citizenship.v1i2.1102

Parmono, K. (2013). Nilai kearifan lokal dalam batik tradisional Kawung. Jurnal Filsafat, 23(2), 134146. http://dx.doi.org/10.22146/jf.13217

Prasetyo, S. A. (2016). Karakteristik motif batik Kendal interpretasi dari wilayah dan letak geografis. Imajinasi: Jurnal Seni, 10(1), 51-60.

Retnowati, T. (2015). Strategi pembelajaran seni lukis anak usia dini di Sanggar Pratista Yogyakarta. Imaji: Jurnal Seni dan Pendidikan Seni, 7(2). doi:https://doi.org/10.21831/imaji.v7i2.6636

Sukmadinata, N. S. (2013). Metode penelitian pendidikan. Bandung: Rosdakarya.

Tocharman, M., \& dkk. (2006). Pendidikan seni rupa. Bandung: UPI Press.

Yudoseputro, W. (1986). Pengantar seni rupa Islam di Indonesia. Bandung: Angkasa.

Yudoseputro, W. (2008). Jejak-jejak tradisi bahasa rupa indonesia lama. Jakarta: Yayasan Seni Visual Indonesia. 